\title{
Block-Holders and Dividends: Evidence from
}

\section{Pakistan}

\section{Shazia Sarwar' ${ }^{1}$, Raheel Mumtaz ${ }^{2}$, M. Farooq Rehan ${ }^{3}$}

${ }^{1}$ M.Phil Commerce, College of Commerce, Government College University, Faisalabad ${ }^{2}$ Assistant Professor, College of Commerce, Government College University, Faisalabad ${ }^{3}$ Assistant Professor, College of Commerce, Government College University, Faisalabad

\section{A B S T R A C T}

This study is designed to examine the effect of multiple large shareholders on dividend pay-outs. We employed the panel data of seventy-five non-financial firms of the KSE-100 index during 2006 to 2018. Results report that multiple large shareholders have a significant negative effect on dividend pay-outs. It implies that a weak legal structure supports large shareholders to expropriate wealth from the minorities. Moreover, we find that firms pay more dividends when they have a high level of profitability, larger assets, lower debt in the capital mix, and greater cash holding. Thus, our study contributes to the scant literature of block-holders and dividend pay-outs policy.

Keywords: Multiple Large Shareholders, Dividend

\section{INTRODUCTION}

Multiple large shareholders collaborate to expropriate wealth and withhold dividend payouts in East Asian countries (Faccio et al., 2001). On the other hand, block-holder has high reinvestment rates and low dividend payouts in European countries (Thomsen, 2004) and Indonesia (Santos et al., 2020; Duygun et al., 2018; Moin et al., 2020; Setiawan et al., 2016) and Hong Kong (Chen et al., 2005). Therefore, block holders have a mixed effect on dividends payouts (Sindhu et al., 2016; Al-Gharaibeh, 2013, Tahir et al., 2014; Laeven \& Levine, 2008)). Hence, blockholders may raise or diminish company value depending on whether incentives are aligned or minority investors are expropriated. Whereas, empirical evidence on this puzzling issue is scarce and yields contradictory results.

Our research objective is to determine the influence of large shareholders on dividend payouts. Some arguments supporting to pay low dividend payouts. Multiple large 
shareholders may prefer low dividends if they obtain private gains from enterprises, dividend policy gives a mechanism to discriminate between the two effects, while minority investors may prefer high payouts that benefit all shareholders (Thomsen, 2004). Kouki \& Guizani, (2009) argue that state large shareholders play a vital role in low dividend payout policy. Moreover, large firms are less willing to pay out high dividends. Additionally, withholding dividend payouts from large shareholders collude with the expropriation of minority shareholder capital (De Cesari, 2012; Mancinelli \& Ozkan, 2006). Conversely, stockholders may need dividends to fulfill their cash flow requirements, if expropriation through tunneling becomes difficult. Consequently, they may work together to force firms to pay high dividends (Faccio et al., 2001; Thanatawee, 2013). Given the argument, it is important to examine the association between larger shareholders and dividend policy to expand a better understanding of corporate dividend decisions (Bakri, 2021).

Large shareholders can motivate, monitor, and discipline management (Nguyen et al., 2022). On the other hand, agency theory not only works out the influence of multiple large shareholders on the dividend payouts. It also deals with agency conflict, particularly between small and large shareholders are raised (i.e. owners with significant voting power). Surely, agency conflict arises and it left an influence on the private benefit to retain cash by managers inside the company at the expense of small shareholders (KIM \& $\mathrm{CHO}, 2021)$. In contrast, in the presence of large shareholders, managerial discretion can be restrained to some extent, and agency costs between managers and shareholders are reduced (Faisal et al., 2020). Hence, corporate payout policy played a less role in addressing agency issues that develop incorporate insiders and outside shareholders. Corporate payouts can serve as a viable corporate governance tool to alleviate these disputes by returning cash to all shareholders and thus minimizing the potential extraction of isolated rentals from major shareholders (Andres et al., 2019; Boubaker et al., 2019).

Our research shows the influence of multiple shareholders on dividends. We find a negative association, aligned with Faccio et al., (2001), Duygun et al., (2018), Moin et al., (2020), Santos et al., (2020), and Gomes \& Novaes, (2001) and their collusion-toextort hypothesis. At first look, our negative relationship appears to be contradictory with 
Gugler \& Yurtoglu, (2003) positive findings and monitoring theory. We consider dividend policy to see if there are any conflicts of interest between stockholders and minority investors. The presence of blockholders has a detrimental impact on payout ratios. Our findings are interpreting the agency conflicts between blockholders and minority shareholders. Minority shareholders fearing expropriation by major owners may prefer dividends to retained earnings, resulting in a reduction in firm value for companies that pay low dividends (Attig et al., 2021; Keinonen, 2021). We expect enterprises with strong large shareholders to pay smaller dividends to the extent that shareholders expropriate minority shareholders when the opportunity arises (Qian \& Tam, 2021).

The remaining research is arranged as follows: the second chapter fundamentally covers the topic regarding the subject. The third chapter provides data, methodologies, model sampling, and a full explanation of variables and the fourth chapter reports results and analysis. The fifth chapter deals with the discussion, limitations, and future direction of the study.

\section{LITERATURE REVIEW}

The goal of this research is to find out how ownership structure affects dividend payment policy. As a result, a thorough review of the literature has been done to comprehend the essential aspects that influence dividend policy. Dividend policy is crucial in preventing potential conflicts between big and small shareholders because it is feasible to limit major shareholders' wealth extraction through dividend payments (Michael C Jensen \& Meckling, 1976). According to the authors, big shareholders dominate, hence dividends can be paid to controlling shareholders to compensate minority shareholders (Faccio et al., 2001).

In a previous study, the position of the largest shareholders is not defined well according to Holderness, (2003). Previous work is done by instance Claessens et al., (2002). A particular shareholder class is the largest shareholder of a corporation. By using their rights, the largest shareholder with the highest voting power can control the decisions of the company. If the large shareholder's decision is the same as the decision of business managers, there would not be much. But sadly, this is not the case most 
administrators of corporations do not behave following the result the conflict which is arisen in the mind of large shareholders is also known as the agencies theory (Anh, 2019). Therefore, there is a cost difficulty that an organization should consider for a particularly large shareholder in an organization all together not to overlook the advantages of having particular large shareholders as the organization administrators may take advantage of the force of the organization applied by such large shareholders (Aluchna et al., 2019). The significant shareholders will squeeze the administration of the organization to implement a dividend strategy that payouts all benefits got to decrease or take out the supervisor's private utilization and, in the end, alleviate the dispute with the agency. Then again, to expend private advantages for themselves and to disregard the advantages for minority shareholders, a dividend plan that doesn't payout a solitary penny as dividends to shareholders may also be implemented by the principal shareholder is also called by name of expropriation.

Agency theory is an idea for the relationship between ownership and dividend policy. Rozeff, (1982) suggests that "a wealth-maximizing corporation adopts an ideal "monitoring/bonding" package that seeks to decrease agency costs" to limit agency conflicts between shareholders and management. According to Michael C Jensen, (1986), when a company's monitoring expenses are low, it is more likely to distribute more of its revenues to its shareholders. The amount to which existing owners, management, lenders, and new investors have agency conflicts within the organization is reflected in dividend policy (Jabeen \& Ahmad, 2019). Aoki, (2014) used an equivalent approach and divided the most important shareholder into dual groups. Mostly the company's largest shareholder and therefore the largest individual shareholders, and developed a u-shaped association among large shareholdings and dividend payout. The largest shareholders were divided into two categories, primarily the company's largest shareholder and the largest individual shareholder, and a U-shaped association between large shareholdings and dividend payouts was established. Minority shareholders also put the burden on the organization to "disgorge cash" when they are vulnerable to exploitation, the company's ownership is supported by a few significant shareholders, or when minority shareholders' legal protection is insufficient (La Porta et al., 2000). 
The relationship between ownership and dividend policy has been studied empirically in several studies. Rozeff, (1982) shows that when individual shareholding is minimal, corporations pay higher dividends (also see (Moh'd et al., 1995). Large shareholders, particularly institutions, prefer cash dividends over retained earnings, according to Barclay et al., (2009) and Short et al., (2002). It is also believed that when a company is controlled by a large number of owners and does not pay dividends, it is valued lower (Thomsen et al., 2006). Significant shareholders have a detrimental impact on firm valuation and dividend payouts in continental European corporations in this situation. "Dividends represent the seriousness of the dispute between the major, controlling owner and minor, outside shareholders," Gugler \& Yurtoglu, (2003) argue, yet their findings suggest that dividend payouts increase as the largest shareholder's holding expands.

The topmost shareholders have considerable agency costs. It played a vital role for them to keep their status for not missing cash from minority shareholders, these actions will leave a harmful impression on their cost if the company's cost droplets (Claessens et al., 2002). According to Grinstein \& Michaely, (2005) the largest shareholder has a strong object to display the aptitude to coordinate several management systems for the improvement of monitoring efficacy. Dividends may use as a remedy which is a proxy monitoring mechanism whether the largest shareholder's volume of monitoring is insufficient, or if the firm suffers from agency conflicts between the blockholders and minority shareholders Rozeff (1982). As an outcome, we hypothesize that, all else being equal, enterprises with higher stages of shareholding by the blockholders are more likely to pay dividends, and that these payments will increase as their stake in the company grows.

In evaluating whether or not this relationship is direct, the influence of the biggest investor to seize cash from minority investors, just as the impetus to control the association's executives, is critical. The biggest investor is bound to zero in on securing the worth of their venture through expanding levels of checking for moderately humble degrees of property. With the more dynamic greater part of investor checking, profits become less important as an observing device, and circulations might diminish in 
response to expansions in the biggest investor's property, to some degree at the outset. As the number of offers held by the biggest investor develops, the best investor can apply command over the organization's tasks and dispossess assets from minority investors. As the biggest investor's position develops, the degree of profits is probably going to ascend to keep up with powerful oversight. Crutchley et al., (1999) and Khan, (2006) discovered that the largest shareholder's holdings and dividend policy had a convex relationship.

It's likely that the greater part investor's personality regardless of whether it's an insider, a monetary establishment, or the public authority is significant Gugler \& Yurtoglu, (2003). is significant Gugler \& Yurtoglu, (2003). Investors might have more control over corporate arrangement and execution than different partners (Juhmani, 2020). Strong insiders, for example, might need to remove leases from held income rather than profits Grossman \& Hart, 1988). High-profit payouts require all the more much of the time related to capital raising, which requires more market observing(Easterbrook, 1984). Financial firms may choose cash dividends for tax reasons (Ouyang et al., 2020), for sustainability (Barclay et al., 2009), or to meet "prudent man" norms (Grinstein \& Michaely, 2005). Therefore, we guess that when the biggest investor is an insider, organizations will be less inclined to deliver profits. Companies whose essential financial backer is a monetary foundation can anticipate the converse.

The controversy between managers and shareholders about the dispute is more than two centuries old. Adam Smith (1776) believed that administrators would not act with as much commitment as owners. Since then, many facets of the organizational issue have been highlighted in the literature. These concerns differ in terms in terms of firm features as well as financial and governance structure. Several studies have recently shifted the emphasis to internal conflicts of interests that shareholders may face. Controlling insiders have discovered a clear sign of widespread minority shareholder expropriation (La Porta et al., 2000). There are different ways of expropriation, such as outright robbery. Selling of properties and goods at unfair rate related parties, offering unqualified relative lucrative jobs or unfairly executives. Expropriation induces inefficiency in the financial system in the sense that, in the face of potential expropriation by insiders, fund providers would be willing to surrender their wealth. The legal way to govern expropriation is to 
establish and enact legislation effectively (La Porta et al., 1997).

The ability to monitor company management and shareholder rights differs by country and legal system, which has an impact on the degree of conflicts of interest (La Porta et al., 2000). In countries with inadequate legal protection, the largest shareholders can act as a check on management by forcing them to pay out additional funds, cutting potential agency costs (Jiang et al., 2020). Minority investors, then again, are more successful in applying their freedoms to shield themselves from possible seizure in nations with solid lawful insurance. Thus, the legitimate assurance is given to minority investors in the locale in which the organization works affects the connection between the biggest investor and profit strategy.

\subsection{Proposed Theoretical Framework}

The effect blockholders and dividend payouts: evidence from non-financial firms in Pakistan from 2006 to the year 2018 are shown in figure 2.1

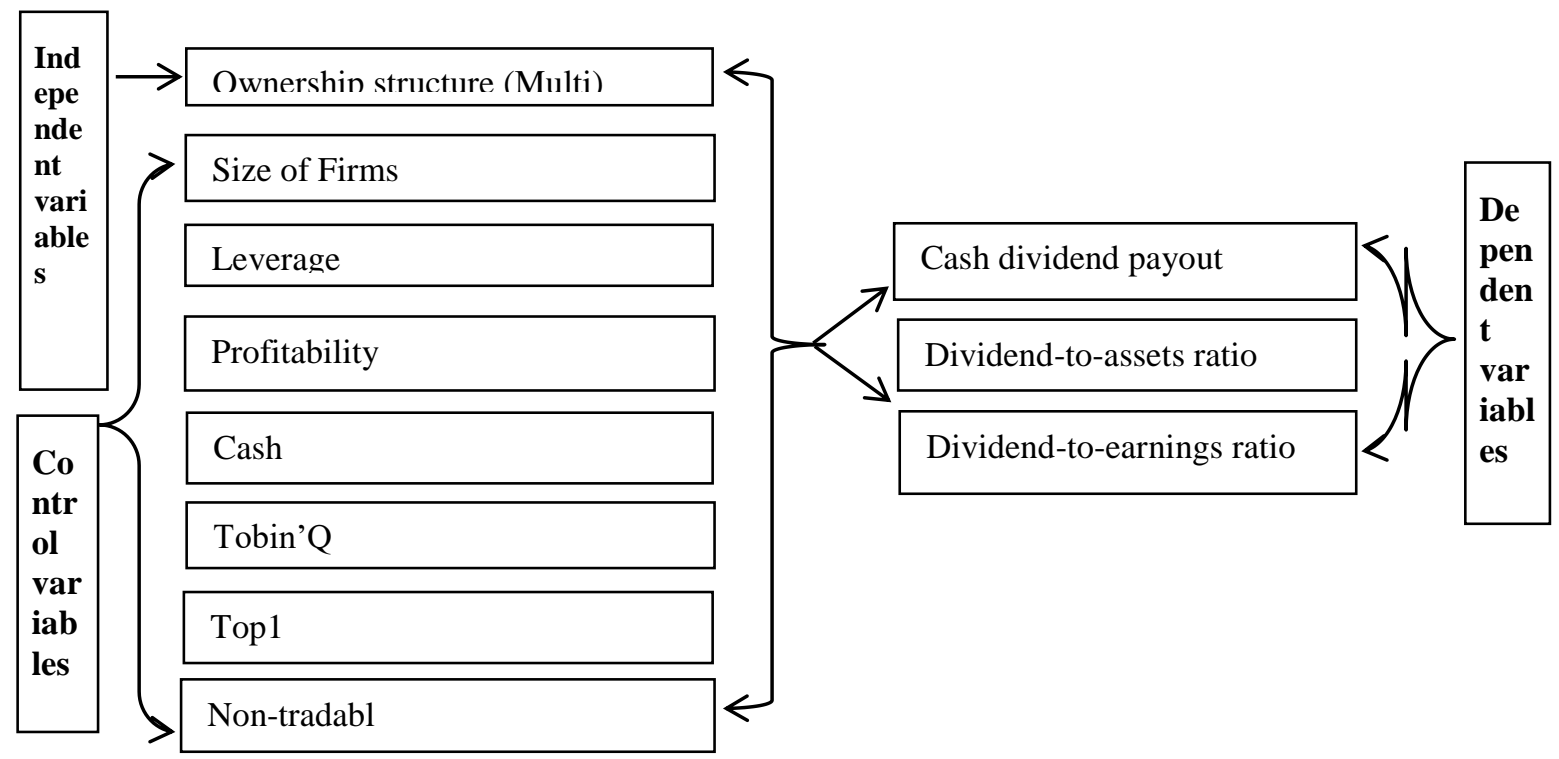

Figure 2.1: Theoretical Framework

The theoretical framework is shown in figure 2.1. Independent variable is mentioned as multiple large shareholders and control variables are labeled as the size of firms, leverage, profitability, cash, Tobin' $\mathrm{Q}$, and toplin influencing the dependent variables 
cash dividend payout, dividend-to-assets ratio, and dividend-to-earnings ratio.

\section{RESEARCH METHODOLOGY}

The research design methodology section consists of data collection and sample size different econometric models and the definition of variables used in this study.

\subsection{Sample Size and Data Collection}

Collection of data from the Karachi stock exchange (KSE) for this report. This study sample includes 75 companies randomly selected from the listed non-financial firms KSE-100 index and collected annually from 2006-2018 from the 12 years. This work left with 760 observations which after removing the differences from the findings are used in this study. The sample involves largely non-financial firms from various manufacturing companies such as textiles, cement, telecommunication companies, power generation, petroleum companies, fertilizer companies, oil companies, refining industry, etc. Because of the reason that the financial structure of financial firms such as banks, asset management firms, insurance firms, etc. Varies from that of non-financial firms which are included. The data collected for the research has the same duration.

The research in this study is based on secondary data. Collected data consists of financial statements. The different sources are used for finding data:

1. Annual report

2. Pakistan stock exchange website

3. The annual report collects the company website.

4. Collects annual report open door website

\subsection{Econometric Model}

In this analysis phase-wise regression. Since the first proxy, IFDIV, is an indicator variable, a logit model should be used (logistic binary regressions). Cash dividend payout is binary, thus only two conditions (either 0 or 1 ). For designing a Tobit model, the other two variables, DIV_ta and DIV_e are left-censored at zero. The purpose of this stepwise regression is to check for the explanation of each blockholders type on the dividend.

First Model: Cash dividend payout and blockholders

IFDIV it

$$
=\operatorname{Logit}\left(\alpha_{i t}+\beta_{1} \text { MULTI }_{i t}+\beta_{2} \text { TOP1 }_{i t}+\beta_{3} \operatorname{SIZE}_{i t}+\beta_{4} \mathrm{LEV}_{i t}+\beta_{5} \mathrm{ROA}_{i t}+\beta_{6} \mathrm{CASH}_{\mathrm{it}}\right.
$$


$+\beta_{7}$ TOBIN'Q $_{i t}+\beta_{8}$ NON- TRADABLE ${ }_{i t}+e_{i}+e_{t}$

Second Model: Dividend-to-earnings ratio and blockholders

DIV_e it

$=$ Tobit $\left(\alpha_{\mathrm{it}}+\beta_{1} \mathrm{MULTI}_{\mathrm{t} t}+\beta_{2} \mathrm{TOP}_{\mathrm{it}}+\beta_{3} \mathrm{SIZE}_{\mathrm{it}}+\beta_{4} \mathrm{LEV}_{\mathrm{it}+} \beta_{5} \mathrm{ROA}_{\mathrm{it}}+\beta_{6} \mathrm{CASH}_{\mathrm{it}}\right.$ $+\beta_{7}$ TOBIN'Q $_{i t}+\beta_{8}$ NON-TRADABLE $\mathrm{it}_{\mathrm{t}}+\mathrm{e}_{\mathrm{i}}+\mathrm{e}_{\mathrm{t}}$

Third Model: $\quad$ Dividend-to-assets ratio and blockholders

DIV_ta it $_{\text {t }}$

$=$ Tobit $\left(\alpha_{i t}+\beta_{1}\right.$ MULTI $_{i t}+\beta_{2}$ TOP1 $_{i t}+\beta_{3} \mathrm{SIZE}_{\mathrm{it}}+\beta_{4} \mathrm{LEV}_{\mathrm{it}+} \beta_{5} \mathrm{ROA}_{\mathrm{it}}+\beta_{6} \mathrm{CASH}_{\mathrm{it}}$ ${ }_{+} \beta_{7}$TOBIN'$_{\mathrm{it}+} \beta_{8}$ NON-TRADABLE ${ }_{\mathrm{t}}+\mathrm{e}_{\mathrm{i}}+\mathrm{e}_{\mathrm{t}}$

\subsection{Definition of Variables}

\section{Dependent Variables}

In our main analysis, we used three proxies to calculate payout propensity and dividend amounts. The first one is called a cash dividend payout If our total cash dividends exceed for the year zero the indicator variable IFDIV equals 1 otherwise it equals 0 which is nominated by DeAngelo et al., (2006), Denis \& Osobov, (2008), and Fama \& French, (2001). The second one is used for dividend earnings ratio, the DIV_e ratio is used as $\mathrm{n}$ indicator proxy. It is used for getting yearly dividend payouts. Examined by John et al., (2011). The third is Dividend-To-Assets Ratio, DIV_ta ratio is identified as the indicator variable. It is easy getting by total cash dividend payout by total asset, examined by Michaely \& Roberts, (2012).

\section{Independent Variables}

A shareholder can own or more from the company's remaining shares, he or she is mentioned to as "large" or "blockholders." This idea is parallel to those which may use by Maury et al., (2005) and Laeven \& Levine, (2008). A dummy variable is MULTI and its value is probably equal to 1 if the company has two large shareholders holding at least $10 \%$ of the remaining shares, and zero otherwise.

\section{Control Variables}

The analysis also contains these company-specific variables. The reasons control variables are required. Large, profitability of the firm is a high level of cash, leverage of 
firm low and few growth opportunities are more like to pay a dividend (DeAngelo et al., 2006 John, 2011; Fama, 2001; Denis \& Osobov, 2008; Michaely \& Roberts, 2012). we use Firm Size (SIZE) for calculating firm scale, the natural log of the total asset is used. Thus, the proxy would be used by (Kumar et al., 2015). The largest Shareholder's Shareholding (TOP1) measured is the by the percentage of shares held by the largest shareholder explained by John et al., (2011). Leverage (LEV) is calculated by the longstanding debt ratio divided by total assets term liabilities, also used by Cheng et al., (2014). We used Profitability (ROA) as net income divided by total assets according to Makri et al., (2014) using the following formula. Cash Holding (CASH) to calculate cash holding, the availability of measuring cash of firm divided by total assets. The proxy would be used by Jiang et al., (2017). Growth Opportunity (TOBIN'Q) to compare the market value of equity plus book value of liability by total assets is called Tobin's $Q$ according to (Jiang et al., 2019). Non-tradable Share (NON-TRADABLE) for analyzing non-tradable control variables that are equal to the ratio of non-tradable number of shares to the total outstanding numeral of shares of the firm, according to Jiang et al., (2017). For further detail, the appendix can be clarified.

\section{RESULTS AND ANALYSIS}

\subsection{Descriptive Statistics}

In this paper, descriptive statistics of all dependent and independent variables are shown in Table 4.1. This table provides the central tendency (mean), percentile points, and standard deviation (variation from mean value) of variables in the data set of observations KSC 100 index non-financial sectors. So, the column "Mean" shows the average value, column Std. dev. demonstrates the standard deviation of sample observations. The 25th and 75th percentile explain the width of the value of a variable, which reports for twenty-five percent of values in the dataset are located below and above the unique value, and the minimum and maximum values show the lowest and highest value of our data respectively. 


\begin{tabular}{|l|c|c|c|c|c|c|c|}
\hline \multicolumn{1}{|c|}{ TABLE 4.1. SUMMARY STATISTICS } \\
\hline \multicolumn{1}{|c|}{ VARIABLES } & mean & $\mathrm{sd}$ & $\mathrm{min}$ & $\mathrm{p} 25$ & $\mathrm{p} 50$ & $\mathrm{p} 75$ & $\mathrm{max}$ \\
\hline IFDIV & .7467 & .4352 & 0 & 0 & 1 & 1 & 1 \\
\hline DIV_e & .2398 & 1.893 & -.499 & 0 & .2767 & .5071 & .9686 \\
\hline DIV_ta & .04974 & .07485 & 0 & 0 & .02317 & .06632 & .3607 \\
\hline MULTI & .5197 & .4999 & 0 & 0 & 1 & 1 & 1 \\
\hline TOP1 & .40107 & .24657 & 0 & .21008 & .34838 & .56334 & .95022 \\
\hline SIZE & 16.758 & 1.4123 & 12.928 & 15.969 & 16.772 & 17.676 & 19.682 \\
\hline LEV & .50281 & .2180 & .04936 & .3147 & .5181 & .67437 & .95169 \\
\hline ROA & .11657 & .13582 & .21 & .0355 & .10265 & .1789 & .5313 \\
\hline CASH & .07334 & .10404 & .00046 & .00765 & .02706 & .09657 & .46871 \\
\hline TOBIN'Q & 1.7799 & 1.8667 & .34962 & .91808 & 1.2395 & 1.8817 & 9.5365 \\
\hline NON-TRADABLE & .40489 & .35395 & 0 & 0 & .42575 & .6804 & .9765 \\
\hline
\end{tabular}

*SOURCE: AUTHORS' COMPUTATION: Table 4.1in this study, summary statistics mean, median maximum, minimum, and standard deviation of the explained and explanatory variables IFDIv stand for cash dividend payout, DIV_e stand for Dividend-to-earnings and DIV_ta stand for Dividend-to-assets and MULTI stand for ownership structure and other all variables SIZE stand for firm size, LEV stand for firm leverage, TOPI stand for the largest shareholder's shareholding, ROA stand for profitability ratio, CASH stand for holding cash, TOBIN'Q stand for a growth opportunity and NON-TRADABLE stand for the proportion of non-tradable share. The sample size consists of non-financials KSE-100 index, 75 firm's year, and observation 760 from 2006 to 2018.

REPRESENT* statistical significance at the $1 \%$ level of respect.

Table 4.1 shows that $74.67 \%$ of non-financial firms included in KSE-100 have paid cash dividend IFDIV during the period 2006 to 2018. The IFDIV average shows, the propensity to pay dividends is $74 \%$ of the total dividends of firms, and $26 \%$ of the cash dividend is not paid in non-financial firms. The mean value of IFDIV is $74 \%$ while the standard deviation is 0.5243 which means that risk will be low than to pay a cash dividend. The IFDIV min value of $0 \%$ and the max value of $1 \%$ show that the value prevails in 0 to 1 which shows that there is a very high variation prevailing in the data values. Therefore, the minimum value is zero which means the firm has paid not any dividend in these years. The mean (median) values of DIV_e and DIV_ta are 23.98\% (27.67\%) and $4.974 \%$ (2.317\%) respectively. Therefore, the DIV_e ratio shows an equivalent payout propensity of Pakistani firms (74\%) or a similar payout ratio (23\%) which is related to $69.3 \%$ payout propensity and a $27.9 \%$ payout ratio in Chinese firms (Jiang et al., 2019). At least two or more blockholders are necessary for the firm's 
ownership structure (MULTI) to have $51.97 \%$. The large shareholders (TOP 1) of the firms have a mean value of $40.107 \%$, the sample firms' ownership structure is highly concentrated, with a maximum value of $95.022 \%$. Other main control variables are explained consistently with previous studies e.g., Jiang et al., (2017). In this study, the descriptive statistic results of Pakistani firms in comparison to Chinese firms are in line with Jiang et al., (2019) and La Porta et al., (2000).

\subsection{Correlation Analysis}

The correlation analysis was utilized in this study to examine the association between independent and dependent variables. It also helps in identifying the strength of the relationship and the nature of the relationship i.e., positive or negative.

Table 4.2. Correlation Matrix

\begin{tabular}{|l|l|l|l|l|l|l|l|l|l|l|l|}
\hline & IfDIV & DIV_e & $\begin{array}{c}\text { DIV } \\
\text { ta }\end{array}$ & MULTI & TOP1 & SIZE & LEV & ROA & CASH & TOBIN & $\begin{array}{l}\text { NON- } \\
\text { TRADABLE }\end{array}$ \\
\hline IfDIV & 1 & & & & & & & & & \\
\hline DIV_e & 0.068 & 1 & & & & & & & & & \\
\hline DIV-ta & 0.429 & 0.019 & 1 & & & & & & & & \\
\hline MULTI & -0.137 & 0.048 & -0.052 & 1 & & & & & & & \\
\hline TOP1 & 0.0369 & 0.003 & 0.2217 & -0.145 & 1 & & & & & & \\
\hline SIZE & 0.122 & 0.063 & 0.029 & -0.066 & 0.22 & 1 & & & & & \\
\hline LEV & -0.219 & -0.00 & -0.159 & 0.101 & -0.04 & 0.087 & 1 & & & & \\
\hline ROA & 0.509 & 0.086 & 0.644 & -0.003 & 0.19 & 0.001 & -0.31 & 1 & & & \\
\hline CASH & 0.229 & 0.027 & 0.290 & -0.017 & 0.15 & -0.05 & -0.12 & 0.27 & 1 & & \\
\hline TOBIN'Q & 0.13 & 0.03 & 0.50 & 0.000 & 0.29 & -0.03 & -0.07 & 0.33 & 0.16 & 1 \\
\hline $\begin{array}{l}\text { NON- } \\
\text { TRADABLE }\end{array}$ & -0.08 & -0.03 & 0.04 & 0.01 & 0.29 & 0.12 & -0.05 & 0.02 & -0.09 & 0.19 & 1 \\
\hline NOTE & & &
\end{tabular}

NOTE *Source: Authors' Computation: Correlation means the correlation between two variables or the path of variables, whether they are related to each other positively or negatively. A Pearson correlation matrix table 4.2 the explained and explanatory variables IFDIv stand for cash dividend payout, DIV_e stand for Dividend-to-earnings and DIV_ta stand for Dividend-to-assets and MULTI stand for ownership structure and other variables SIZE stand for firm size, LEV stands for firm leverage, TOPI stands for the largest shareholder's shareholding, ROA stands for profitability ratio, CASH stand for holding cash, TOBIN'Q stand for a growth opportunity and NON-TRADABLE stand for the proportion of non-tradable share. The sample size consists of non-financial firms KSE100 index, 75 firms, and of observation 760 from 2006 to 2018

REPRESENT* $1 \%$ level of significance respectively.

The Pearson correlations between the variables are shown in Table 4.2. Not surprisingly, the three dividend payout variables (IFDIV, DIV_ta, and DIV_e) are 
extremely correlated. The positive association between MULTI and DIV_e is that firms pay at a higher level of dividends with multiple blockholders. The first variable DIV_e measures are also a positive correlation with TOP1, SIZE, ROA, CASH, and TOBIN'Q and a negative correlation with LEV and NON-TRADABLE. The negative correlation between both dependent variables IFDIV and DIV_ta with MULTI is that firms are not paying a higher level of dividends with multiple blockholders. The second variable IFDIV has a positive relationship with TOP1, SIZE, ROA, CASH, and TOBIN'Q. The increment in these variables tends to increase in IFDIV. But IFDIV has a negative correlation with LEV and NON-TRADABLE. The third variable DIV_ta has a positive relationship with the firm's size, profitability, cash holding, larger shareholders shareholding, NON-TRADABLE, and TOBIN'Q. However, the increment in these variables tends to increase in DIV_ta. But DIV_ta has a negative correlation with LEV which shows the increase in these tends to decrease the value of DIV_ta. Payoff measures and control factors relationships are linked with past concepts and studies. Further, a cash dividend is positively linked by SIZE, and LEV has negatively associated with a cash dividend. Such finding can be viewed as endorsing forecast the prediction that is consistent with the results of prior studies by (Ahmed \& Javid, 2008; Faccio et al., 2001; Fama \& French, 2001; Gul, 1999; Huang et al., 2011; Jiang et al., 2019; John et al., 2011; Kalay, 1982; Liu et al., 2014; Wu et al., 2009)

\subsection{Regression Analysis}

The results of the econometrical regression models, explanations of the results, and suggestions, as well as managerial implications, are presented in this section of the study. Statistical approaches for estimating relationships between a dependent variable and one or more independent variables, as well as predicting how they will interact in the future. Table 4.3.1, 4.3.2, and 4.3.3 show the regression results of the first, second, and third Models. Model 1 is the outcome of logistic regression (Logit model) for all sample companies, including IFDIV, a dummy variable that's valued is equal to 1 then the company's total cash dividend for the year are more than zero. The dependent variable is left-censored at zero, DIV_ta, and DIV_e. Since we are implementing a Tobit model using 2 and 3 models. R-squared is a goodness-of-fit criterion for regression models. 
When all of the independent variables are applied together, this statistic represents the percentage of difference in the dependent variables that the independent variables account for. R-squared measures the frequency of the association between the model and outfit on a comfortable 0-100 percent scale. The table below shows the test results for each model. Their standard errors will be listed in parentheses. Statistical importance is shown by $*, * *, * * *$ at the ten percent, five percent, and one percent rate, respectively. Since residuals can be linked across companies, standard errors are clustered across all experiments it is decided to use the total $\mathrm{R}$ squared number.

\begin{tabular}{|c|c|c|c|c|c|c|c|}
\hline \multirow{3}{*}{ VARIABLES } & \multicolumn{3}{|c|}{ MODEL 1} & \multicolumn{2}{|c|}{ MODEL 2} & \multicolumn{2}{|c|}{ MODEL 3} \\
\hline & \multicolumn{3}{|c|}{ IFDIV } & \multicolumn{2}{|c|}{ DIV_e } & \multicolumn{2}{|c|}{ DIV_ta } \\
\hline & COEF. & Prob. & $\begin{array}{l}\text { ODDS } \\
\text { RATIO }\end{array}$ & COEF. & Prob. & COEF. & Prob. \\
\hline MULTI & -.89052 & $0.00 * * *$ & .410438 & -.518004 & $0.00 * * *$ & -.489844 & $0.000 * * *$ \\
\hline TOP1 & -1.4954 & $0.012 * *$ & .2241481 & -.724463 & $0.020 * *$ & -.792090 & $0.010 * *$ \\
\hline SIZE & .43274 & $0.00 * * *$ & 1.541468 & .2399713 & $0.000 * * *$ & .2562834 & $0.000 * * *$ \\
\hline LEV & -.56225 & 0.315 & .5699263 & -.441150 & 0.161 & -.416898 & 0.181 \\
\hline ROA & 18.718 & $0.00 * * *$ & $1.34 \mathrm{e}+08$ & 8.898822 & $0.000 * * *$ & 8.803406 & $0.000 * * *$ \\
\hline CASH & 5.3722 & $0.00 * * *$ & 215.3349 & 2.822993 & $0.002 * * *$ & 2.748347 & $0.003 * * *$ \\
\hline TOBIN'Q & .10045 & 0.171 & 1.105664 & .0556935 & 0.190 & .0656578 & 0.109 \\
\hline $\begin{array}{l}\text { NON- } \\
\text { TRADABLE }\end{array}$ & -.60483 & 0.141 & .5461662 & -.457961 & $0.025 * *$ & -.424313 & $0.037 * *$ \\
\hline _CONS & -6.3590 & $0.0 * * *$ & .0017311 & -3.41347 & $0.000 * * *$ & -3.64407 & $0.000 * * *$ \\
\hline LR CHI2 (8) & \multicolumn{3}{|c|}{316.96} & \multicolumn{2}{|c|}{309.77} & \multicolumn{2}{|c|}{314.86} \\
\hline PROB > CHI2 & \multicolumn{3}{|c|}{0.0000} & \multicolumn{2}{|c|}{0.0000} & \multicolumn{2}{|c|}{0.0000} \\
\hline PSEUDO R2 & \multicolumn{3}{|c|}{0.3866} & \multicolumn{2}{|c|}{0.3767} & \multicolumn{2}{|c|}{0.3689} \\
\hline $\begin{array}{l}\text { LOG } \\
\text { LIKELIHOOD }\end{array}$ & \multicolumn{3}{|c|}{-251.47632} & \multicolumn{2}{|c|}{-256.32418} & \multicolumn{2}{|c|}{-269.2964} \\
\hline
\end{tabular}


Table 4.3 shows the baseline regression results that the correlation between ownership structure and cash dividend payout. The cash dividend is a dummy variable so use the Logit model used only for a binary variable that is assigned 1 to pay the dividends of firms and otherwise 0 . The two other dependent variables DIV_e measured by total cash dividend to net income. DIV_ta is measured by total cash dividend to total assets. These are dependent variables that use the Tobit regression model with left censoring at zero. The explanatory variable is MULTI, which is as dummy variable two conditions ( 0 or 1$)$, that is equivalent to 1 if the company has at least 2 major shareholders owning at $10 \%$ of the share, and 0 if it does not. This study uses another variable is the control variable SIZE stand for firm size calculated by the natural log of total asset, LEV stands for form leverage to measure by the total debt to total asset, profitability is measured by the net income by total assets net, CASH standing by cash holding to calculated by cash holding scaled by total asset, TOP1 stand by largest shareholder's shareholding to measure by the \% by largest share held by large shareholder's, TOBIN'Q stand for growth opportunities measure by the market value of equity plus book value of liability by total assets, NON-TRADABLE stand for the proportion of non-tradable share measure by the ratio of the number of non-tradable control variables that are equal to the ratio of non-tradable number of shares to the total outstanding numeral of shares of the firm. $\mathrm{R}^{2}$ is the coefficient to determination and it represents \% change in factor $\mathrm{N}$ is total observation 760 number of researches. This is used three levels of significance. Uncertainty the P-value is 0.01 and less than 0.01 then a highly significant level of $1 \%$ and if the p-value is 0.05 and less than 0.05 then it will be significant at $5 \%$. Then if the P-value is 0.1 and less than 0.1 it is significant at $10 \%$ but not as highly significant as $1 \%$ or $5 \%$. The sample size is used in this research KSE-100 index.

Note: * indicates significant variables. $1 \% * * *, 5 \% * *$ and $10 \% *$ * Source: Authors' Computation:

This model shows blockholders have a negative influence on dividend payouts. If MULTI $\mathrm{p}$ has a value not cross the $5 \%$ then multiple has a significant impact on dividend payouts, level of significance at $1 \%$. Therefore, the result is significant that why rejecting $\mathrm{H} 0$ and $\mathrm{H} 1$ is accepted in this model, because MULTI has $\mathrm{p}<5 \%$. Thus, the firm has less likely to pay the dividend to shareholders. Increases in ownership are employed as an internal governance tool to decipher the opportunistic conduct of the business manager and to match the interests of the shareholders with those of the managers, resulting in a negative relationship between dividend payouts and ownership.

However, TOP1 has a negative and significant association with dividend payouts, with a significance level of $5 \%$. Now the p-value has not achieved the target of more than $5 \%$. Hence, $\mathrm{H} 1$ is accepted or rejected $\mathrm{H} 0$ because TOP1 has $\mathrm{p}<5 \%$. We find the size of firms has a positive and significant effect on dividend payouts at $1 \%$. If the SIZE p-value is less than 5\%, the result is significant that why rejecting $\mathrm{H} 0$ and $\mathrm{H} 1$ is accepted in this model. Suggest that there would be a positive shift in dividend distribution with the growth in the size of the group. This can be reinforced by in conflict that firms allocate more dividends with good belief, reliability, and likely for payouts. This size measure is 
intended to counteract the effects of expansion in a typical company over time. We expect large companies to be more mature, with stronger access to financial markets and institutions, and hence to be more likely to pay dividends and further payments (Huang et al., 2011).

The coefficient result of LEV has a non-significant and negative effect on dividend payouts in table 4.3. Therefore, the result is $\mathrm{H} 1$ is rejected and $\mathrm{H} 0$ is accepted in this model, because LEV has p>5\%. Dividends and debt both can diminish cash inflows, therefore debt can be used to mitigate agency difficulties instead of dividends. Furthermore, loan covenants may place restrictions on dividend distributions. Management can, however, employ debt to augment dividends in reducing free cash flows (Huang et al., 2011). Moreover, the coefficient of ROA has a positive impact on dividend payouts, significant aa $1 \%$ level. Hence, the result is significant that why $\mathrm{H} 1$ is accepted in this model. However, rejecting H0 because ROA has $\mathrm{p}<5 \%$.

As data showed in figure 4.3 hence the $\mathrm{CASH}$ has a positive impact on dividend payouts. If the $\mathrm{CASH}$ p-value is less than $5 \%$ because rejecting $\mathrm{H} 0$ and $\mathrm{H} 1$ is accepted in this model. Consequently, CASH has a significant positive impact on dividend payouts at a level of $1 \%$. Moreover, we use TOBIN'Q as an indicator that shows a company's opportunities for growth. Table 4.3 shows that firms with higher TOBIN'Q pay lower dividends, as predicted by the considerably positive coefficients on TOBIN'Q, but nonsignificant because the p-value is larger than $5 \%$. Therefore, $\mathrm{H} 1$ is rejected and $\mathrm{HO}$ is accepted in this model. To put it another way, multiple blockholders aren't sacrificing future development prospects in exchange for higher dividend payouts at the expense of smaller investors.

As data shown in table 4.3 coefficient of NON-TRADABLE has a negative impact on dividend payouts. Subsequently, the NON-TRADABLE has a non-significant influence on IFDIV. Thus, the consequence is non-significant that why $\mathrm{H} 1$ is rejected than $\mathrm{H} 0$ will be accepted because NON-TRADABLE has $\mathrm{p}>5 \%$. Our result of the other two variables NON-TRADABLE has a significant impact on DIV_ta and DIV_e. Therefore, rejection of $\mathrm{H} 0$ and $\mathrm{H} 1$ will be accepted is due to NON-TRADABLE having $\mathrm{p}<5 \%$, significant level of NON-TRADABLE is $5 \%$. The relation between dependent and 
independent variables is indicated by $\mathrm{R} 2$. The value of $\mathrm{R} 2$ here is $0.3866,0.3767$ and 0.3689 indicates that independent and control variables describe $38.6 \%, 37.6 \%$ and $36.8 \%$ dependent variables. The relationship here is very strong and the model's fitness is also fine.

According to (Mancinelli \& Ozkan, 2006) results are supporting the earlier study so, the option of the most important shareholder features a considerably negative impact on the dividend payouts of the corporate. The watching power of "solid" large shareholders, excluding the most important, is extremely tiny, in step with these findings. However, this conclusion could be attributed in part to the impact of shareholder agreements on dividend policy. We find evidence that the presence of options syndicates has influenced the company's payout policy. That's mentioned, the dividend payout is higher once blockholders are controlled along by a coalition. According to Chu et al., (2019) and Moin et al., (2020) results are supporting SIZE and ROA as a significant positive influence on dividends, the firm has bound to pay more dividends. Leverage has a nonsignificant harmful influence on dividend payouts that is why the firm leverage is gone higher than to pay lower dividends. The result indicates that blockholders' ownership is excessive from a minority shareholder viewpoint and that private benefits may be a motive for retaining rather than paying them out as dividends.

\section{CONCLUSION}

We explored the correlation between blockholders and dividend payouts using data from the KSE-100 index. The previous study has indicated either a negative link, which supports the collaborating to expropriate hypothesis proposed by (Faccio et al., 2001), or a favorable relationship, which supports the monitoring hypothesis proposed by (Gugler \& Yurtoglu, 2003). In these experiments, blockholders are likely to desire to withhold payouts. Blockholders in Pakistan, on the other hand, want dividends to raise their economic advantage. This is owing to their inability or unwillingness to sell their nontradable shares to make a profit, or because they do not want to lose control of the business. Dividends are currently one of the few remaining feasible profit opportunities for wealthy owners. As a result, blockholders in Pakistan may band together to compel 
corporations to pay dividends, particularly high payouts. Data observed through the analysis that dividend payout has shown negative effects on blockholders. Significant negative effects were also found by (Chu et al., 2019) in Malaysia and European companies (Thomsen, 2004). Such behaviors show that week's legal structure supports multiple large shareholders to expropriate wealth from the minority (La Porta et al., 2000).

The results show an important negative alliance between blockholders and the payout of dividends. The study enables managers to better understand the relationship between blockholders and dividend payout, and if large blockholders are like to pay a dividend or more like to pay less the dividends. This means that managers must consider these variables when planning the payout of dividends. Single large shareholders can also estimate potential dividend payouts by simply looking at multiple large shareholders. According to this analysis, the company will pay a high amount of cash dividends if there is an increase in block shareholder's holding. Few studies have been carried out on Pakistan's contextual environment; no such research has been conducted to verify the different analyses of various proxies under my best knowledge. For researchers and practitioners working in Pakistan, this study will be beneficial. Thus, our paper contributes to the scarce literature and payout strategy of several large shareholders and, in general, multiple large shareholders have large growing literature. Earlier studies have been carried out on the finding of several major shareholders were both negative and positive relationships observed in different economies of the world. It was observed positive in china (Jiang et al., 2019) and negative in Malaysia (Chu et al., 2019)and European companies (Thomsen, 2004). In our study, we observed a negative relationship in Pakistan's economy. As a result, our research adds to the limited literature on a variety of blockholders and payout techniques. Many prominent shareholders have been shown to collude for private advantage or monitor one another in previous research, but we show that they can also work together to achieve a common purpose.

\subsection{Suggestions for Further research}

1. This exploration is an attempt to analyze the effect on dividends and corporate efficiency of the ownership structure. Some areas could not be explored during 
the ongoing literature review due to the absence of availability of data/time.

2. Data collection and investigation of the conclusion of their involvement in the ownership structure on the dividend payment policy of companies in Pakistan seems to be more suitable for different institutions.

3. This research is confined to non-financial firms; however, the trends of financial firms may be investigated as well.

\section{REFERENCES}

Ahmed, H., \& Javid, A.Y. (2008). The determinants of dividend policy in Pakistan.

Aluchna, M., Berent, T., \& Kamiński, B. (2019). Dividend payouts and shareholder structure: evidence from the Warsaw Stock Exchange. Eastern European Economics, 57(3), 227-250.

Andres, C., et al. (2019). Dividend policy, corporate control, and the tax status of the controlling shareholder. Journal of Industrial Business Economics 46(2), 157189.

Anh, T. T. X. (2019). The Relationship between Ownership Structure and Dividend Policy: An Application in Vietnam Stock Exchange. Academic Journal of Interdisciplinary Studies, 8(2), 131.

Aoki, Y. (2014). How does the largest shareholder affect dividends? International Review of Finance, 14(4), 613-645.

Attig, N., Ghoul, S. El, Guedhami, O., \& Zheng, X. (2021). Dividends and economic policy uncertainty: International evidence. Journal of Corporate Finance, 66.

Bakri, M. A. (2021). DOES DIVIDEND POLICY AFFECT FIRM VALUE IN AN EMERGING MARKET?: EVIDENCE FROM MALAYSIAN FIRMS. Labuan Bulletin of International Business and Finance, 19(1).

Barclay, M.J., et al. (2009). Dividends and corporate shareholders. The Review of Financial Studies, 22(6), 2423-2455.

De Cesari, A. (2012). Expropriation of minority shareholders and payout policy. The British Accounting Review, 44(4), 207-220.

Denis, D.J.,Boubaker, S., et al. (2019). Large shareholders, control contestability and firm productive efficiency. Annals of Operations Research, 1-24.

Chen, Z., et al. (2005). Ownership concentration, firm performance, and dividend policy in Hong Kong. Pacific-Basin Finance Journal 13(4), 431-449.

Cheng, Z., et al. (2014). Free cash flow, growth opportunities, and dividends: Does crosslisting of shares matter? , 30(2), 587-598.

Chu, E.Y., et al. (2019). LARGE SHAREHOLDERS AND DIVIDEND PAYOUT IN MALAYSIA. International Journal of Business Society, 20(1).

Claessens, S., et al. (2002). Disentangling the incentive and entrenchment effects of large shareholdings. The journal of finance, 57(6), 2741-2771.

Crutchley, C.E., et al. (1999). Agency problems and the simultaneity of financial decision making: The role of institutional ownership. International review of financial analysis, 8(2), 177-197.

De Cesari, A. (2012). Expropriation of minority shareholders and payout policy. The British Accounting Review, 44(4), 207-220.

DeAngelo, H., et al. (2006). Dividend policy and the earned/contributed capital mix: a test 
of the life-cycle theory. Journal of Financial economics 81(2), 227-254.

Denis, D.J., \& Osobov, I. (2008). Why do firms pay dividends? International evidence on the determinants of dividend policy. Journal of Financial economics 89(1), 62-82.

Duygun, M., et al. (2018). Dividend policy of Indonesian listed firms: The role of families and the state. Economic Modelling, 75, 336-354.

Faccio, M., et al. (2001). Dividends and expropriation. American economic review 91(1), 54-78.

Faisal, F., Majid, M. S. A., \& Sakir, A. (2020). Agency conflicts, firm value, and monitoring mechanisms: An empirical evidence from Indonesia. Cogent Economics \& Finance, 8(1).

Fama, E., \& French, K. (2001). Disappearing dividends: changing firm characteristics or lower propensity to pay? Journal of Financial economics 60(1), 3-43.

Gomes, A., \& Novaes, W. (2001). Sharing of control as a corporate governance. Retrieved from

Grinstein, Y., \& Michaely, R. (2005). Institutional holdings and payout policy. The Journal of Finance, 60(3), 1389-1426.

Grossman, S.J., \& Hart, O.D. (1988). One share-one vote and the market for corporate control. Journal of financial economics, 20, 175-202.

Gugler, K., \& Yurtoglu, B.B. (2003). Corporate governance and dividend pay-out policy in Germany. European economic review, 47(4), 731-758.

Gul, F.A. (1999). Government share ownership, investment opportunity set and corporate policy choices in China. Pacific-Basin Finance Journal, 7(2), 157-172.

Holderness, C.G. (2003). A survey of blockholders and corporate control. Economic policy review, 9(1).

Huang, J.J., et al. (2011). Nonnegotiable shares, controlling shareholders, and dividend payments in China. Journal of Corporate Finance, 17(1), 122-133.

Jabeen, M., \& Ahmad, M. (2019). Impact of Ownership Structure on Dividend Payout Policy in Cement Industry of Pakistan. European Online Journal of Natural Social Sciences, 8(4), 679-686.

Jensen, M.C. (1986). Agency costs of free cash flow, corporate finance, and takeovers. The American economic review, 76(2), 323-329.

Jensen, M.C., \& Meckling, W.H. (1976). Theory of the firm: Managerial behavior, agency costs and ownership structure. Journal of financial economics, 3(4), 305-360.

Jiang, F., et al. (2019). Multiple large shareholders and dividends: Evidence from China. Pacific-Basin Finance Journal, 57, 101201.

Jiang, F., Ma, Y., \& Wang, X. (2020). Multiple blockholders and earnings management. Journal of Corporate Finance, 64, 101689.

Jiang, F., et al. (2017). Stock liquidity and dividend payouts. Journal of Corporate finance 42, 295-314.

John, K., et al. (2011). Does geography matter? Firm location and corporate payout policy. Journal of financial economics, 101(3), 533-551.

Juhmani, O. I. (2020). CORPORATE BOARDS, OWNERSHIP STRUCTURE AND DIVIDEND PAYOUT: EVIDENCE FROM BAHRAIN. Journal of Critical Reviews, 7(12), 37-43.

Kalay, A. (1982). Stockholder-bondholder conflict and dividend constraints. Journal of financial economics, 10(2), 211-233.

Keinonen, H. M. A. (2021). Blockholders and Firm Performance within the Nordic Corporate Governance Model: Finnish Evidence. Nordic Journal of Business, 70(2), 132-154. https://helda.helsinki.fi/dhanken/handle/10227/437705 
Khan, T. (2006). Company dividends and ownership structure: Evidence from UK panel data. The Economic Journal, 116(510), C172-C189.

KIM, H. S., \& CHO, K.-S. (2021). The Determinants of Blockholder Presence: Evidence from Korea. The Journal of Asian Finance, Economics and Business, 8(12), 29 39. https://doi.org/10.13106/JAFEB.2020.VOL7.NO4.29

Kouki, M., \& Guizani, M. (2009). Ownership structure and dividend policy evidence from the Tunisian stock market. European Journal of Scientific Research 25(1), 42-53.

Kumar, B.R., et al. (2015). Determinants of dividend policy: Evidence from GCC market. $4(1), 17-29$.

La Porta, R., et al. (1997). Legal determinants of external finance. The journal of finance, 52(3), 1131-1150.

La Porta, R., et al. (2000). Agency problems and dividend policies around the world. The Journal of finance, 55(1), 1-33.

Laeven, L., \& Levine, R. (2008). Complex ownership structures and corporate valuations. The Review of Financial Studies, 21(2), 579-604.

Liu, C., et al. (2014). Controlling shareholder, split-share structure reform and cash dividend payments in China. International Review of Economics Finance 29, 339357.

Makri, V., et al. (2014). Determinants of non-performing loans: The case of Eurozone. 61(2), 193-206.

Mancinelli, L., \& Ozkan, A. (2006). Ownership structure and dividend policy: Evidence from Italian firms. European Journal of Finance 12(03), 265-282.

Maury, B., et al. (2005). Multiple large shareholders and firm value. 29(7), 1813-1834.

Michaely, R., \& Roberts, M.R. (2012). Corporate dividend policies: Lessons from private firms. The Review of Financial Studies, 25(3), 711-746.

Moh'd, M.A., et al. (1995). An investigation of the dynamic relationship between agency theory and dividend policy. Financial Review, 30(2), 367-385.

Moin, A., et al. (2020). The effects of ownership structure, sub-optimal cash holdings and investment inefficiency on dividend policy: evidence from Indonesia. Review of Quantitative Finance Accounting 55(3), 857-900.

Nguyen, P. L., Galpin, N., \& Twite, G. (2022). New active blockholders and adjustment of CEO relative incentive ratios. Journal of Corporate Finance, 72, 102127. https://doi.org/10.1016/j.jcorpfin.2021.102127

Ouyang, C., Xiong, J., \& Huang, K. (2020). Do multiple large shareholders affect tax avoidance? Evidence from China. International Review of Economics Finance, 67, 207-224.

Qian, X., \& Tam, L. (2021). Blockholders and corporate governance: evidence from China's split-share-structure reform. Review of Accounting and Finance, 20(1), 53-83.

Rozeff, M.S. (1982). Growth, beta and agency costs as determinants of dividend payout ratios. Journal of financial Research 5(3), 249-259.

Santos, A., et al. (2020). Dividend and leverage in Indonesian intergenerational family firms. Jurnal Siasat Bisnis, 24(1), 43-58.

Setiawan, D., et al. (2016). Ownership structure and dividend policy in Indonesia. Journal of Asia Business Studies.

Short, H., et al. (2002). The link between dividend policy and institutional ownership. Journal of Corporate Finance, 8(2), 105-122.

Sindhu, M.I., et al. (2016). Impact of ownership structure on dividend payout in Pakistani non-financial sector. Cogent Business Management 3(1), 1272815. 
Tahir, S.H., et al. (2014). The impact of board composition and ownership structure on dividend policy in Pakistan. Research journal of economics business studies, 3(6), 18-24.

Thanatawee, Y. (2013). Ownership structure and dividend policy: Evidence from Thailand. International Journal of Economics Finance 5(1), 121-132.

Thomsen, S. (2004). Blockholder Ownership, Dividends and Firm Value In Continental Europe.

Thomsen, S., et al. (2006). Blockholder ownership: Effects on firm value in market and control based governance systems. Journal of Corporate Finance, 12(2), 246269.

Wu, S., et al. (2009). State control, legal investor protection, and ownership concentration: Evidence from China. Corporate Governance: An International Review, 17(2), 176-192.

\section{Appendix}

Table 7.1: Definition of variables

\section{VARIABLES DEFINITION}

IFDIV

A dummy variable that equals 1 if the firm's total cash dividend payouts of the

year are higher than zero.

DIV_e Total cash dividends of the year divided by net income.

DIV_ta Total cash dividends of the year scaled by total assets.

MULTI A dummy variable that equals 1 if the firm has at least two shareholders with at least $10 \%$ of the shares outstanding, and zero otherwise.

TOP1 Percentage of shares held by the largest shareholder.

SIZE The natural logarithm of the book value of total assets.

LEV The ratio of total debts to assets.

ROA Net income scaled by total assets.

CASH Cash holding is scaled by total assets.

TOBIN'Q

NON -

The market value of equity plus the book value of liabilities is divided by total assets.

TRADABLE shares of the firm. 